\title{
Reakcja odmian pszenicy jarej na zróżnicowany poziom intensywności technologii produkcji
}

\author{
Response of spring wheat to varied intensity of crop production technology
}

\section{Aneta Jarecka, Dorota Bobrecka-Jamro, Jan Buczek ${ }^{\bowtie}$, Wacław Jarecki}

\author{
Wydział Biologiczno-Rolniczy, Uniwersytet Rzeszowski \\ $\triangle$ e-mail: jbuczek@ur.edu.pl
}

\begin{abstract}
W badaniach oceniono reakcję odmian pszenicy jarej na dwa zróżnicowane poziomy intensywności technologii uprawy. Doświadczenie przeprowadzono w latach 2013-2015 na polach Zakładu Doświadczalnego Oceny Odmian w Skołoszowie. Uzyskane wyniki badań wykazały, że intensywny poziom technologii produkcji powodował wzrost plonu ziarna pszenicy o 1,6 $\mathrm{t} \cdot \mathrm{ha}^{-1}$, w porównaniu do plonu uzyskanego w technologii średnio intensywnej. Wzrost plonu ziarna pszenicy uprawianej według technologii intensywnej w odniesieniu do technologii średnio intensywnej wynikał z większej liczby kłosów na jednostce powierzchni. Odmiany pszenicy jarej różniły się poziomem plonowania oraz wartością elementów składowych plonu. Największy plon ziarna uzyskała odmiana KWS Torridon, a najmniejszy Izera. Odmiana Izera, KWS Torridon i Tybalt uzyskały największą obsadę kłosów na jednostce powierzchni, z kolei odmiana Parabola uzyskała największą masę 1000 ziaren, a największą liczbę ziaren z kłosa uzyskała odmiana KWS Torridon.
\end{abstract}

\begin{abstract}
Słowa kluczowe: komponenty plonu, plon ziarna, skład chemiczny ziarna
The study assessed response of spring wheat to two different intensity levels in crop production technology. The experiment was conducted from 2013 to 2015 in the fields of the Research Facility for Cultivar Assessment in Skołoszów. The obtained test results showed that the intense level of production technology resulted in an increase in wheat grain yield by $1,6 \mathrm{t} \cdot \mathrm{ha}^{-1}$, compared to the yield obtained in medium-intensity technology. The increase in grain yield of wheat cultivated according to the intensive technology in relation to medium-intensity technology resulted from a larger number of ears per surface unit. Varieties of spring wheat differed in the level of yield and the value of the components of the crop. The highest grain yield was given to KWS Torridon and the smallest to Izera. The Izera, KWS Torridon and Tybalt variety obtained the largest spike casting on the surface unit, while the Parabola variety obtained the largest mass of 1000 grains, and the largest number of grains per ear was KWS Torridon.
\end{abstract}

Key words: grain yield, yield components, chemical composition of grain

\section{Wstęp}

W uprawie pszenicy jarej ważny jest wybór odpowiedniej odmiany oraz zastosowanie właściwej agrotechniki. Głównym wyznacznikiem danej technologii uprawy jest poziom zużycia środków produkcji takich jak nawozy mineralne czy środki ochrony roślin. Efektem zwiększonej intensyfikacji produkcji jest najczęściej przyrost plonów a często i poprawa cech jakościowych ziarna (Kołodziejczyk i Szmigiel, 2014). Z dotychczasowych badań wynika, że głównym elementem agrotechniki wpływającym na wielkość i jakość plonu ziarna jest nawożenie mineralne azotem. Wpływ ten uzależniony jest jednak od wielu czynników, takich jak: formy nawozu, terminu zastosowania, dawki oraz sposobu aplikacji (Ali i in., 2012). Zalecana dawka azotu pod pszenicę jarą waha się w szerokich granicach $60-160 \mathrm{~kg} \cdot \mathrm{ha}^{-1}$ (Velasco $\mathrm{i}$ in., 2012), przy czym stosowanie dużych dawek nawozów azotowych sprzyja wyleganiu roślin oraz silniejszemu porażeniu przez choroby. Następstwem tego może być istotny spadek plonu oraz pogorszenie jakości zbieranego ziarna
(Korbas i Mrówczyński, 2014). Ważnym elementem agrotechniki pszenicy jest ochrona chemiczna roślin. Straty powodowane przez agrofagi mogą wynosić od $10 \%$ do $50 \%$, a w latach dużego ich nasilenia jeszcze więcej (Horoszkiewicz-Janka i in., 2013). Należy zaznaczyć, że optymalizacja poziomu nawożenia azotem oraz ochrony roślin uzależniona jest od reakcji poszczególnych odmian pszenicy oraz interakcyjnego wpływu czynników siedliskowych i agrotechnicznych (Szempliński, 2012). We współczesnym rolnictwie europejskim zaleca się praktykowanie takiego poziomu uprawy, który pozwoli uzyskać zadowalający plon ziarna a zarazem zmniejszyć niekorzystny wpływ przemysłowych środków produkcji na środowisko naturalne. Redukcja dawek nawozów azotowych czy środków ochrony roślin pozwala na urzeczywistnienie idei zrównoważonego rolnictwa (Korbas i Mrówczyński, 2009). Intensywne technologie produkcji przy długotrwałym stosowaniu mogą niekorzystnie wpływać na środowisko naturalne. Obecnie propagowany jest integrowany system produkcji, w którym konieczne jest umiejętne powiązanie całokształtu 
agrotechniki $\quad \mathrm{z}$ ograniczonym zużyciem przemysłowych środków produkcji. W rezultacie zwiększa się efektywności ponoszonych nakładów i minimalizuje ujemne oddziaływania rolnictwa na środowisko przyrodnicze (Kołodziejczyk i Szmigiel, 2014). Boczar (2015) twierdzi, że kosztowną ochronę roślin warto zastąpić innymi elementami agrotechniki jak: płodozmian, sposób uprawy, zbilansowane nawożenie czy dobór odmian a dopiero na końcu sięgać po środki ochrony roślin.

Celem badań była ocena reakcji odmian pszenicy jarej na zróżnicowany poziom technologii produkcji (średnio intensywny $\mathrm{i}$ intensywny).

\section{Materiał i metody badań}

Ścisłe doświadczenie polowe przeprowadzono w latach 2013-2015. Zlokalizowane zostało na polach Stacji Doświadczalnej Oceny Odmian w Skołoszowie. Doświadczenie założone zostało w układzie split-plot w czterech powtórzeniach. Pierwszym czynnikiem doświadczenia był poziom technologii produkcji: średnio intensywny A1 i intensywny A2. Drugim badanym czynnikiem było 12 odmian pszenicy jarej: Izera, Ostka Smolicka, Parabola, Struna, KWS Torridon, Tybalt, Arabella, Bombona, Kandela, Katoda, Łagwa i Monsun. Badane technologie różniły się między innymi poziomem nawożenia mineralnego oraz ochroną przed chorobami grzybowymi i wyleganiem (tab. 1).

Tabela 1

Table1

Charakterystyka technologii stosowanych w uprawie pszenicy jarej

Diversification of agrotechnical treatments on two levels of cultivation

\begin{tabular}{|c|c|c|c|c|}
\hline \multirow{2}{*}{$\begin{array}{c}\text { Rodzaj nawozu - preparatu Type of } \\
\text { fertilizer - preparation }\end{array}$} & \multirow{2}{*}{$\begin{array}{c}\text { Nawóz, preparat } \\
\text { Fertilizer, preparation }\end{array}$} & \multirow{2}{*}{$\mathrm{BBCH}$} & \multicolumn{2}{|c|}{ Technologia - Technology } \\
\hline & & & $\mathrm{A} 1$ & $\mathrm{~A} 2$ \\
\hline $\begin{array}{l}\text { Zaprawa nasienna } \\
\text { Seed dressing }\end{array}$ & Funaben $\mathrm{T}$ & 00 & $\begin{array}{l}200 \mathrm{~g} / 100 \mathrm{~kg} \text { ziarna - } \\
\text { seeds }\end{array}$ & $\begin{array}{l}200 \mathrm{~g} / 100 \mathrm{~kg} \text { ziarna - } \\
\text { seeds }\end{array}$ \\
\hline $\begin{array}{l}\text { Nawóz azotowy } \\
\text { Nitrogen fertilizer }\end{array}$ & Saletra amonowa $34 \%$ & - & $80 \mathrm{~kg} \cdot \mathrm{ha}^{-1}$ & $140 \mathrm{~kg} \cdot \mathrm{ha}^{-1}$ \\
\hline $\begin{array}{l}\text { Insektycyd } \\
\text { Insecticide } \\
\end{array}$ & $\begin{array}{l}\text { Cyperkill Max } 500 \text { EC } \\
\text { (cypermetryna) }\end{array}$ & $59-65$ & $0,05 \mathrm{dm}^{-3} \cdot \mathrm{ha}^{-1}$ & $0,05 \mathrm{dm}^{-3} \cdot \mathrm{ha}^{-1}$ \\
\hline $\begin{array}{l}\text { Herbicyd } \\
\text { Herbicide }\end{array}$ & $\begin{array}{l}\text { Sekator } 125 \text { OD (amidosulfuron, } \\
\text { jodosulfuron metylosodowy) }\end{array}$ & $13-29$ & $0,15 \mathrm{dm}^{-3} \cdot \mathrm{ha}^{-1}$ & $0,15 \mathrm{dm}^{-3} \cdot \mathrm{ha}^{-1}$ \\
\hline Fungicyd & $\begin{array}{l}\text { Falcon } 460 \text { EC (spiroksamina, } \\
\text { tebukonazol, triadimenol) }\end{array}$ & 33 & - & $0,6 \mathrm{dm}^{-3} \cdot \mathrm{ha}^{-1}$ \\
\hline Fungicide & $\begin{array}{l}\text { Artea } 330 \text { EC (propikonazol, } \\
\text { cyprokonazol) }\end{array}$ & 59 & & $0,5 \mathrm{dm}^{-3} \cdot \mathrm{ha}^{-1}$ \\
\hline $\begin{array}{l}\text { Nawóz dolistny } \\
\text { Foliar fertilizer } \\
\end{array}$ & Insol 3 & 39 & - & $1,5 \mathrm{dm}^{-3} \cdot \mathrm{ha}^{-1}$ \\
\hline $\begin{array}{l}\text { Regulator wzrostu } \\
\text { Growth regulator }\end{array}$ & $\begin{array}{l}\text { Antywylegacz } 675 \text { SL (chlorek } \\
\text { chlormekwatu) + Modus } 250 \text { EC } \\
\text { (trineksapak etylu) }\end{array}$ & $31-32$ & - & $\begin{array}{l}1,0 \mathrm{dm}^{-3} \cdot \mathrm{ha}^{-1} \\
0,3 \mathrm{dm}^{-3} \cdot \mathrm{ha}^{-1}\end{array}$ \\
\hline
\end{tabular}

Doświadczenie założono na glebie kompleksu pszennego bardzo dobrego, klasy bonitacyjnej II. Była to gleba zaliczana do czarnoziemu zdegradowanego wytworzonego $\mathrm{z}$ lessu, o składzie granulometrycznym pyłu zwykłego, według Systematyki gleb Polski opracowanej przez Polskie Towarzystwo Gleboznawcze w 2011 roku. Z punktu widzenia kategorii agronomicznej była to gleba średnia. Charakteryzowała się odczynem lekko kwaśnym. Zawartość próchnicy $\mathrm{w}$ glebie była średnia. Zawartość $\mathrm{N}_{\min } \mathrm{w}$ glebie była niska w każdym badanym roku. Zawartość przyswajalnego fosforu $\mathrm{w}$ glebie wahała się od średniej (13,4 mg na $100 \mathrm{~g}$ gleby) w $2015 \mathrm{r}$. do bardzo wysokiej (23,7 mg na 100 g gleby) w 2014 r. Gleba pod doświadczeniami odznaczyła się średnią lub bardzo wysoką zawartością potasu przyswajalnego i bardzo wysoką zawar- tością magnezu przyswajalnego (tab. 2). Powierzchnia pojedynczego poletka wyniosła $15,0 \mathrm{~m}^{2}$. Głębokość siewu wyniosła $3 \mathrm{~cm}$, a szerokość międzyrzędzi $12,5 \mathrm{~cm}$.

Tabela 2

Table 2

\begin{tabular}{l|l|c|c|c}
\multicolumn{5}{c}{ Wyniki analizy gleby } \\
Results of soil analysis \\
\hline \multicolumn{1}{c}{ Parametr } & Jednostka & 2013 & 2014 & 2015 \\
\hline pH w KCL & - & 5,65 & 6,06 & 5,90 \\
Próchnica & $\%$ & 1,89 & 1,95 & 2,01 \\
$\mathrm{Humus}$ & $\mathrm{kg} \cdot \mathrm{ha}^{-1}$ & 67,2 & 58,3 & 52,8 \\
$\mathrm{~N}_{\text {min }}$ & $\mathrm{mg} / 100 \mathrm{~g}$ & 15,5 & 23,7 & 13,4 \\
$\mathrm{P}_{2} \mathrm{O}_{5}$ & 20,0 & 27,5 & 12,7 \\
$\mathrm{~K}_{2} \mathrm{O}$ & $\mathrm{gleby} / \mathrm{soil}$ & 13,6 & 13,3 & 12,3 \\
$\mathrm{Mg}$ &
\end{tabular}


W fazie dojrzałości pełnej określono plon ziarna oraz jego składowe (liczbę kłosów na $1 \mathrm{~m}^{2}$, masę 1000 ziaren i liczbę ziaren $\mathrm{z}$ kłosa).

Porażenie przez choroby oceniono w skali 9-stopniowej, przy czym $9^{\circ}$ oznacza stan rolniczo najlepszy, a $1^{\circ}$ stan najgorszy.

Ocena jakościowa ziarna obejmowała oznaczenie zawartości białka ogólnego, skrobi, popiołu i włókna surowego. Oznaczenia wykonano metodą NIRS w bliskiej podczerwieni na aparacie Spektrometr FT-NIR MPA firmy Bruker (Niemcy).

Istotność różnic pomiędzy wartościami cech stwierdzono na podstawie półprzedziałów ufności Tukeya, przy poziomie istotności $\alpha=0,05$. Obliczenia wykonano programem statystycznym FR-ANALWAR-5FR.

\section{Wyniki i dyskusja}

Warunki pogodowe oceniano na podstawie miesięcznej sumy opadów oraz średniej miesięcznej temperatury powietrza. Dane uzyskano $\mathrm{z}$ polowej automatycznej stacji meteorologicznej umieszczonej na terenie pól doświadczalnych. Warunki pogodowe były zróżnicowane w latach badań (tab. 3). W marcu 2013 r. suma opadów była wysoka $(107,2 \mathrm{~mm})$ w porównaniu do średniej $\mathrm{z}$ wielolecia $(35,6 \mathrm{~mm})$, przy ujemnych temperaturach powietrza. Wpłynęło to na opóźnienie wiosennych zasiewów pszenicy jarej. W kwietniu każdego roku opady deszczu kształtowały się poniżej średnich opadów z wielolecia. W latach 2013 i 2014 w omawianym miesiącu temperatury były wyższe od notowań $\mathrm{z}$ wielolecia. Korzystne warunki pogodowe odnotowano $\mathrm{w}$ maju każdego roku. Dużą sumą opadów charakteryzował się czerwiec 2013 r., zaś niską czerwiec 2015 r. W lipcu i sierpniu temperatury powietrza były wyższe od średnich $\mathrm{z}$ wielolecia. Najcieplejszymi miesiącami były lipiec $\left(21,2^{\circ} \mathrm{C}\right)$ i sierpień $\left(21,9^{\circ} \mathrm{C}\right)$ w 2015 roku oraz lipiec $\left(21,0^{\circ} \mathrm{C}\right)$ w 2014 roku. W lipcu najniższe opady odnotowano w 2013 r. Z kolei w sierpniu opady poniżej średniej z wielolecia wystąpiły w latach 2013 i 2015. Dmowski i Dzieżyc (2009) podają, że pszenica jara wymaga rocznej sumy opadów mieszczącej się w granicach od 450 do $530 \mathrm{~mm}$ $\mathrm{i}$ średniej temperatury powietrza $\mathrm{w}$ zakresie od 12,5 do $15,5^{\circ}$ C. Staniszewski i Woźniak (2007) konkludują, że warunki hydrotermiczne istotnie wpływają na uzyskiwany plon oraz jakość ziarna pszenicy zwyczajnej jarej.

W prezentowanych badaniach wykazano istotny wpływ intensywności technologii produkcji na plonowanie pszenicy jarej. Wzrost intensywności technologii produkcji powodował zwiększenie plonu ziarna pszenicy o $1,6 \mathrm{t} \cdot \mathrm{ha}^{-1}, \mathrm{tj}$. $29 \%$ w porównaniu do plonu uzyskanego w technologii średnio intensywnej. Najwyższy plon ziarna uzyskała odmiana KWS Torridon, a istotnie mniejszy Izera. Średni ogólny plon ziarna wyniósł 6,3 $\mathrm{t} \cdot \mathrm{ha}^{-1}$ (tab. 4).

Warunki pogodowe w latach 2013-2015

Weather conditions in the years 2013-2015

\begin{tabular}{|c|c|c|c|c|c|c|c|c|}
\hline \multirow{2}{*}{$\begin{array}{l}\text { Miesiące } \\
\text { Months }\end{array}$} & \multicolumn{4}{|c|}{$\begin{array}{c}\text { Suma opadów }(\mathrm{mm}) \\
\text { Total precipitation }(\mathrm{mm})\end{array}$} & \multicolumn{4}{|c|}{$\begin{array}{c}\text { Średnie temperatury powietrza }\left({ }^{\circ} \mathrm{C}\right) \\
\text { Mean air temperature }\left({ }^{\circ} \mathrm{C}\right)\end{array}$} \\
\hline & 2013 & 2014 & 2015 & Multi-year & 2013 & 2014 & 2015 & Multi-year \\
\hline$\overline{\text { III }}$ & 107,2 & 58,2 & 32,7 & 35,6 & $-1,7$ & 6,9 & 5,4 & 2,7 \\
\hline IV & 33,8 & 29,5 & 24,4 & 45,7 & 9,3 & 10,1 & 8,7 & 8,9 \\
\hline V & 71,0 & 88,6 & 64,3 & 69,4 & 15,8 & 15,1 & 13,6 & 14,1 \\
\hline VI & 107,6 & 70,6 & 20,4 & 77,5 & 18,6 & 16,1 & 17,9 & 16,6 \\
\hline VII & 39,7 & 106,1 & 114,4 & 91,9 & 20,0 & 21,0 & 21,2 & 18,8 \\
\hline VIII & 25,8 & 65,3 & 14,3 & 63,7 & 19,7 & 19,2 & 21,9 & 18,1 \\
\hline
\end{tabular}


Wpływ technologii produkcji na plon ziarna i komponenty plonu pszenicy jarej The impact of cultivation technology on yield components and grain yield

\begin{tabular}{|c|c|c|c|c|}
\hline $\begin{array}{l}\text { Czynnik } \\
\text { Factor }\end{array}$ & $\begin{array}{c}\text { Liczba kłosów na } \mathrm{m}^{2} \\
\text { The number of ears per } \mathrm{m}^{2}\end{array}$ & \begin{tabular}{|c|} 
Liczba ziaren w kłosie \\
Number of grains in the ear
\end{tabular} & $\begin{array}{l}\text { MTN (g) } \\
\text { TSW (g) }\end{array}$ & $\begin{array}{l}\text { Plon }\left(t \cdot h a^{-1}\right) \\
\text { Yield }\left(t \cdot h a^{-1}\right)\end{array}$ \\
\hline \multicolumn{5}{|c|}{ Poziom intensywności technologii uprawy - The level of intensity of cultivation technology } \\
\hline A1 & 498,9 & 31,8 & 39,5 & 5,5 \\
\hline A2 & 504,0 & 33,2 & 40,7 & 7,1 \\
\hline NIR $_{0,05} \mathrm{~A}$ & 4,59 & r.n. & r.n. & 1,46 \\
\hline \multicolumn{5}{|c|}{ Odmiana - Cultivar } \\
\hline Izera & 509,6 & 28,9 & 39,0 & 5,4 \\
\hline Ostka Smolicka & 479,2 & 31,6 & 39,7 & 5,8 \\
\hline Parabola & 501,8 & 30,9 & 45,3 & 6,8 \\
\hline Struna & 506,9 & 30,6 & 39,2 & 5,9 \\
\hline KWS Torridon & 509,2 & 37,9 & 38,8 & 7,2 \\
\hline Tybalt & 509,1 & 33,8 & 39,4 & 6,6 \\
\hline Arabella & 496,6 & 32,7 & 36,9 & 5,8 \\
\hline Bombona & 498,3 & 32,9 & 36,6 & 5,8 \\
\hline Kandela & 502,3 & 35,9 & 38,4 & 6,6 \\
\hline Katoda & 494,7 & 31,7 & 42,0 & 6,3 \\
\hline Łagwa & 503,3 & 29,8 & 42,9 & 6,2 \\
\hline Monsun & 507,5 & 32,9 & 42,6 & 6,9 \\
\hline $\mathrm{NIR}_{0,05} \mathrm{~B}$ & 24,09 & 6,31 & 8,26 & 1,75 \\
\hline $\begin{array}{l}\text { Średnia ogólna } \\
\text { Mean total }\end{array}$ & 501,5 & 32,5 & 40,1 & 6,3 \\
\hline
\end{tabular}

r.n. —różnica nieistotna — non-significant difference

O efektach uprawy pszenicy jarej decyduje dobór odpowiedniej odmiany, na co wskazują liczne badania (Kołodziejczyk i in., 2007; Oleksy i in., 2008; Kołodziejczyk i Szmigiel, 2014). W badaniach Kołodziejczyka i Szmigla (2014) średni plon ziarna pszenicy jarej uprawianej według technologii intensywnej był większy o $26,5 \%$ od plonu uzyskanego w uprawie średnio intensywnej. Zastosowanie wyższego poziomu intensywności technologii uprawy (A2) w porównaniu do niższego (A1) skutkowało zwiększeniem obsady kłosów na $1 \mathrm{~m}^{2}$. Nie zmodyfikowało jednak liczby ziaren w kłosie czy MTZ. Komponenty składowe plonu były istotnie zróżnicowane pomiędzy odmianami. Sułek i Cacak-Pietrzak (2008) uzyskały większą masę 1000 ziaren pszenicy pod wpływem wzrastającej doglebowej dawki azotu, przy czym reakcja poszczególnych odmian była niejednakowa. Biskupski i in. (2007) nie wykazali natomiast istotnego zróżnicowania MTZ w wyniku zwiększenia doglebowej dawki azotu. Mrówczyński (2013) podaje, że niedobór azotu ogranicza wzrost i rozwój rośliny, a w efekcie potencjał plonotwórczy, zaś jego nadmiar zwiększa wyleganie oraz porażenie przez niektóre choroby.

W latach badań na obiekcie $\mathrm{z}$ intensywnym poziomem technologii uprawy odnotowano mniejsze porażenie roślin przez choroby w odniesieniu do obiektu ze średnio intensywnym poziomem technologii uprawy. Odmiany pszenicy jarej różniły się stopniem porażenia przez choroby (tab. 5).

$\mathrm{W}$ przeprowadzonym doświadczeniu pszenica jara była porażona przede wszystkim przez septoriozą liści (średnio 7,92 ${ }^{\circ}$ i septoriozą plew (średnio $7,97^{\circ}$ ). Góral i in. (2012) wykazali, że wybór odpornej odmiany oraz właściwa agrotechnika w tym ochrona chemiczna znacząco zmniejszają porażenie chorobami roślin pszenicy jarej $\mathrm{w}$ sytuacji znacznego ich nasilenia. Łozowicka i in. (2007) dodają, że jeśli środki ochrony roślin stosowane są zgodnie z zasadami dobrej praktyki rolniczej, to ilość niebezpiecznych substancji $w$ plonach nie przekracza dopuszczalnych wartości. Ciekawe badania $\mathrm{z}$ tego zakresu przeprowadzili Rachoń $\mathrm{i}$ in. (2017) wykazując zróżnicowanie porażenia przez choroby pomiędzy gatunkami i odmianami pszenic oraz $\mathrm{w}$ zależności od intensyfikacji technologii uprawy.

Poziom intensywności technologii produkcji zmodyfikował tylko zawartość białka ogólnego w ziarnie (tab. 6).

Uzyskana różnica pomiędzy poziomem intensywnym a średnio intensywnym wyniosła $8 \mathrm{~g} \cdot \mathrm{kg}^{-1}$ s.m. Średnio ziarno pszenicy jarej zawierało $\mathrm{w} \mathrm{g} \cdot \mathrm{kg}^{-1}$ s.m.: białka ogólnego 139 , skrobi 621, popiołu 18,4 i włókna 20,9. Zawartość wymienionych składników była zmienna w ziarnie badanych odmian. Wysoką zawartością białka ogólnego odznaczyła się odmiana Izera, Łagwa i Bombona. Natomiast 
dużo skrobi zawierało ziarno odmiany Struna, popiołu Bombona, a włókna KWS Torridon. Spośród wielu czynników, najsilniej na wielkość i jakość plonu ziarna pszenicy oddziałuje azot, który stymuluje pobieranie innych składników i $\mathrm{w}$ największym stopniu wpływa na wzrost zawartości białka (Nowak i Zbroszyczyk, 2003). Poza tym nawożenie azotem pszenicy zwiększa wydajność glutenu oraz poprawia inne wyróżniki jakościowe ziarna (Buczek i in., 2011; Rachoń i in., 2013). Woźniak i Gontarz (2003) podają, że chemiczne środki ochrony roślin istotnie zwiększały zawartość białka ogółem w ziarnie pszenicy jarej o $0,3 \%$ i glutenu mokrego o 3,7\%, w stosunku do obiektów pielęgnowanych tylko mechanicznie.

Tabela 5

Table 5

Porażenie roślin przez choroby

Degree of plant diseases

\begin{tabular}{|c|c|c|c|c|c|c|}
\hline \multicolumn{7}{|c|}{ Degree oi prami unseases } \\
\hline $\begin{array}{l}\text { Czynnik } \\
\text { Factor }\end{array}$ & $\begin{array}{c}\text { Mączniak } \\
\text { prawdziwy - } \\
\text { liście } \\
(49 \mathrm{BBCH}) \\
\end{array}$ & $\begin{array}{c}\text { Brunatna } \\
\text { plamistość liści } \\
(55 \mathrm{BBCH})\end{array}$ & $\begin{array}{l}\text { Rdza brunatna } \\
(59 \mathrm{BBCH})\end{array}$ & $\begin{array}{l}\text { Septorioza liści } \\
(55 \mathrm{BBCH})\end{array}$ & $\begin{array}{l}\text { Septorioza plew } \\
(73 \mathrm{BBCH})\end{array}$ & $\begin{array}{c}\text { Fuzarioza kłosów } \\
\text { (73 BBCH) }\end{array}$ \\
\hline \multicolumn{7}{|c|}{ Poziom intensywności technologii uprawy - The level of intensity of cultivation technology } \\
\hline$\overline{\mathrm{A} 1}$ & 7,63 & 7,74 & 8,26 & 7,64 & 7,64 & 7,79 \\
\hline $\mathrm{A} 2$ & 8,40 & 8,26 & 8,81 & 8,21 & 8,29 & 8,22 \\
\hline \multicolumn{7}{|c|}{ Odmiana - Cultivar } \\
\hline Izera & 7,83 & 7,92 & 8,50 & 7,92 & 8,33 & 8,00 \\
\hline Ostka Smolicka & 7,67 & 8,25 & 8,08 & 7,83 & 8,25 & 8,25 \\
\hline Parabola & 8,25 & 8,42 & 8,33 & 7,75 & 7,50 & 7,50 \\
\hline Struna & 8,17 & 8,33 & 8,67 & 8,33 & 8,08 & 7,92 \\
\hline KWS Torridon & 8,08 & 8,00 & 8,83 & 8,08 & 7,58 & 7,83 \\
\hline Tybalt & 8,33 & 7,67 & 8,83 & 8,08 & 7,92 & 8,33 \\
\hline Arabella & 8,58 & 7,58 & 8,50 & 7,75 & 7,83 & 7,92 \\
\hline Bombona & 7,58 & 7,92 & 8,25 & 8,00 & 8,33 & 8,25 \\
\hline Kandela & 8,50 & 8,08 & 8,75 & 8,25 & 8,17 & 8,17 \\
\hline Katoda & 7,75 & 7,83 & 8,67 & 7,42 & 7,75 & 7,92 \\
\hline Łagwa & 7,83 & 7,83 & 8,50 & 7,75 & 8,00 & 8,00 \\
\hline Monsun & 7,50 & 8,17 & 8,50 & 7,92 & 7,83 & 8,00 \\
\hline $\begin{array}{l}\text { Średnia ogólna } \\
\text { Mean total }\end{array}$ & 8,01 & 8,00 & 8,53 & 7,92 & 7,97 & 8,01 \\
\hline
\end{tabular}

Tabela 6

Table 6

Skład chemiczny ziarna odmian pszenicy jarej w g•kg s.m.

Chemical composition of grain in $\mathrm{g}$ DM

\begin{tabular}{|c|c|c|c|c|}
\hline $\begin{array}{l}\text { Czynnik } \\
\text { Factor }\end{array}$ & $\begin{array}{l}\text { Białko ogólne } \\
\text { Total protein }\end{array}$ & $\begin{array}{l}\text { Skrobia } \\
\text { Starch }\end{array}$ & $\begin{array}{c}\text { Włókno surowe } \\
\text { Fiber }\end{array}$ & $\begin{array}{c}\text { Popiół } \\
\text { Ash }\end{array}$ \\
\hline \multicolumn{5}{|c|}{$\begin{array}{l}\text { Poziom intensywności technologii uprawy } \\
\text { The level of intensity of cultivation technology }\end{array}$} \\
\hline$\overline{\mathrm{A} 1}$ & 137 & 632 & 20,6 & 18,4 \\
\hline A2 & 145 & 610 & 21,1 & 18,5 \\
\hline NIR $_{0,05} \mathbf{A}$ & 6,35 & r.n. & r.n. & r.n. \\
\hline \multicolumn{5}{|c|}{ Odmiana - Cultivar } \\
\hline Izera & 146 & 618 & 19,5 & 18,2 \\
\hline Ostka Smolicka & 133 & 627 & 20,7 & 18,7 \\
\hline Parabola & 143 & 616 & 18,8 & 18,7 \\
\hline Struna & 131 & 643 & 18,6 & 17,2 \\
\hline KWS Torridon & 132 & 610 & 24,1 & 18,6 \\
\hline Tybalt & 143 & 614 & 23,4 & 19,4 \\
\hline Arabella & 135 & 622 & 21,3 & 18,3 \\
\hline Bombona & 144 & 611 & 20,7 & 19,9 \\
\hline Kandela & 142 & 630 & 19,0 & 18,5 \\
\hline Katoda & 132 & 626 & 21,5 & 17,8 \\
\hline Łagwa & 144 & 598 & 22,6 & 18,7 \\
\hline Monsun & 136 & 633 & 20,2 & 17,3 \\
\hline $\mathrm{NIR}_{\mathbf{0 , 0 5}} \mathrm{B}$ & 5,6 & 42,3 & 2,2 & $\mathbf{0 , 8}$ \\
\hline $\begin{array}{l}\text { Średnia ogólna } \\
\text { Mean total }\end{array}$ & 139 & 621 & 20,9 & 18,4 \\
\hline
\end{tabular}

r.n. — różnica nieistotna, non-significant difference 


\section{Wnioski}

1. Wzrost intensywności technologii produkcji powodował zwiększenie plonu ziarna pszenicy o $1,6 \mathrm{t} \cdot \mathrm{ha}^{-1}$, w porównaniu do plonu uzyskanego $\mathrm{w}$ technologii średnio intensywnej.

2. Wzrost plonu ziarna pszenicy uprawianej według technologii intensywnej w odniesieniu do technologii średnio intensywnej wynikał $\mathrm{z}$ większej liczby kłosów na jednostce powierzchni.

3. Odmiany pszenicy jarej różniły się poziomem plonowania oraz wartością elementów składowych plonu. Największy plon uzyskała odmiana KWS Toridon, a najmniejszy Izera. Odmiana Izera, Kws Toridon i Tybalt uzyskały największą obsadę kłosów na jednostce powierzchni, z kolei odmiana Parabola uzyskała największą masę 1000 ziaren, a największą liczbę ziaren z kłosa uzyskała odmiana KWS Toridon.

4. Wzrost intensywności technologii produkcji powodował istotne wzrost zawartości białka ogólnego w ziarnie pszenicy jarej. Natomiast nie zaznaczył się wpływ technologii produkcji na zawartość skrobi, włókna i popiołu w ziarnie pszenicy. Uprawa pszenicy w technologii intensywnej ograniczyła porażenie roślin przez choroby grzybowe $\mathrm{w}$ porównaniu do technologii średnio intensywnej. $Z$ ocenianych chorób w największym nasileniu występowała septorioza liści i plew.

\section{Literatura}

Ali A., Khaliq T., Ahmad A., Ahmad S., Malik A. U., Rasul F. 2012. How wheat responses to nitrogen in the field? A review. Crop and Environment 3 (1-2): $71-76$.

Biskupski A., Kaus A., Włodek S., Pabin J. 2007. Zróżnicowanie nawożenia azotem a plonowanie i wybrane wskaźniki architektury łanu kilku odmian pszenicy jarej. Inżynieria Rolnicza. 3 (91): $29-36$.

Boczar P. 2015. Konkurencyjność w produkcji pszenicy na świecie - wybrane elementy. Zagadnienia Doradztwa Rolniczego 4: $68-84$.

Buczek J., Bobrecka-Jamro D., Jarecki W. 2011. Plon i jakość ziarna wybranych odmian pszenicy jarej $\mathrm{w}$ zależności od dawki i terminu stosowania azotu. Fragmenta Agronomica 28 (4): $7-15$.

Dmowski Z., Dzieżyc H. 2009. Potrzeby opadowe pszenicy jarej na glebach kompleksów pszennego dobrego i żytniego bardzo dobrego w północno-wschodniej Polsce. Acta Agrophysica. 13 (1): $39-48$.

Góral T., Ochodzki P., Walentyl-Góral D., Nielsen L., Justesen A., Jorgensen L. 2012. Wpływ przedplonu oraz warunków pogodowych na porażenie kłosów pszenicy jarej przez grzyby z rodzaju Fusarium oraz zawartość mikotoksyn w ziarnie. Biul. IHAR 265: 11 -21 .

Horoszkiewicz-Janka J., Korbas M., Mrówczyński M. (pod red.). 2013. Metodyka integrowanej ochrony pszenicy ozimej i jarej dla producentów. IOR - PIB Poznań. 74.

Kołodziejczyk M., Szmigiel A. 2014. Wpływ intensywności technologii uprawy na plonowanie wybranych odmian pszenicy jarej. Fragmenta Agronomica 31 (3): 75 84.

Kołodziejczyk M., Szmigiel A., Oleksy A. 2007. Wpływ intensywności uprawy na plonowanie wybranych odmian pszenicy jarej. Acta Scientiarum Polonorum, Agricultura 6 (4): 5 - 14.

Korbas M., Mrówczyński M. (pod red.) 2009. Integrowana produkcja pszenicy ozimej i jarej. IOR - PIB Poznań. ss. 168.

Korbas M., Mrówczyński M. (red.) 2014. Metodyka integrowanej produkcji pszenicy ozimej i jarej. IOR PIB Poznań: 90 ss.

Łozowicka B., Kaczyński P., Rutkowska E. 2007. Pozostałości środków ochrony roślin w ziarnach zbóż. Postępy w Ochronie Roślin. 47 (4): 70 - 74.

Mrówczyński M. (red.) 2013. Integrowana ochrona upraw rolniczych. Tom II. Zastosowanie integrowanej ochrony. PWRiL, Poznań: 286 ss.

Nowak W., Zbroszyczyk T. 2003. Wpływ poziomu intensywności uprawy na zawartość składników mineralnych w ziarnie pszenicy. Zeszyty Problemowe Postępów Nauk Rolniczych. 493: 439 - 445.

Oleksy A., Szmigiel A., Kołodziejczyk M. 2008. Wpływ intensywności uprawy na zawartość i plon białka odmian pszenicy ozimej. Acta Scientiarum Polonorum, Agricultura. 7 (1): $47-56$.

Rachoń L., Szumiło G., Kurzydłowska I. 2013. Wpływ intensywności technologii produkcji na jakość ziarna pszenicy zwyczajnej, twardej, orkiszu i jednoziarnistej. Annales UMCS, Sec. E, Agricultura. 68 (2): $60-68$.

Rachoń L., Szumiło G., Bobryk-Mamczarz A. 2017. Ocena porażenia przez choroby grzybowe wybranych gatunków pszenicy jarej w zależności od intensyfikacji technologii uprawy. Fragmenta Agronomica 34 (2): 75 -83 .

Staniszewski N., Woźniak A. 2007. Wpływ warunków pogodowych na jakość technologiczną ziarna pszenicy jarej i pszenicy ozimej. Acta Agrophysica 9 (2): 525 540.

Sułek A., Cacak-Pietrzak G. 2008. Kształtowanie się cech jakościowych ziarna odmian pszenicy jarej w zależności od nawożenia azotem. Fragmenta Agronomica 25 (1): $400-409$.

Szempliński W. (red.). 2012. Rośliny rolnicze. Uniwersytet Warmińsko-Mazurski w Olsztynie: 407 ss.

Velasco J.L., Rozas H.S., Echeverrí a H.E. Barbieri P.A. 2012. Optimizing fertilizer nitrogen use efficiency by intensively managed spring wheat in humid regions: Effect of split application. Canadian Journal of Plant Science. 92: $847-856$.

Woźniak A., Gontarz D. 2003. Wpływ przedplonów i sposobów zróżnicowanego pielęgnowania na jakość ziarna pszenicy jarej. Biul. IHAR. 228: $33-39$. 


\section{Podziękowanie}

Serdeczne podziękowania dla Pana mgr inż.

Krzysztofa Ochmańskiego - Kierownika

Zakładu Doświadczalnego Oceny Odmian

wSkotoszowie oraz Wspótpracowników

zaokazana pomoc podczas realizacji

trzyletniego doświadczenia polowego. 
